Western University

Scholarship@Western

$1-2013$

\title{
The Effect of Voluntary Disclosure on Firm Risk and Firm Value: Evidence from Management Earnings Forecasts
}

Stephen R. Foerster

Ivey School of Business

Stephen G. Sapp

Ivey School of Business

Yaqi Shi

Ivey School of Business

Follow this and additional works at: https://ir.lib.uwo.ca/iveypub

Part of the Business Commons

Citation of this paper:

Foerster, Stephen R.; Sapp, Stephen G.; and Shi, Yaqi, "The Effect of Voluntary Disclosure on Firm Risk and Firm Value: Evidence from Management Earnings Forecasts" (2013). Business Publications. 41.

https://ir.lib.uwo.ca/iveypub/41 


\title{
The Effect of Voluntary Disclosure on Firm Risk and Firm Value: Evidence from Management Earnings Forecasts
}

\author{
Stephen R. Foerster \\ Professor of Finance Richard \\ Ivey School of Business \\ University of Western Ontario \\ 1151 Richmond Street North \\ London, Canada N6A 3K7 \\ Tel: 519661 3726; Fax 5196613431 \\ Email: sfoerster@ivey.ca \\ Stephen G. Sapp Associate \\ Professor of Finance Richard \\ Ivey School of Business \\ University of Western Ontario \\ 1151 Richmond Street North \\ London, Canada N6A 3K7 \\ Tel: 519661 3006; Fax 5196613485 \\ Email: ssapp@ivey.ca \\ Yaqi Shi* \\ Assistant Professor of Accounting \\ Richard Ivey School of Business \\ University of Western Ontario \\ 1151 Richmond Street North \\ London, Canada N6A 3K7 \\ Tel: 519661 4097; Fax 5196613485 \\ Email: yshi@ivey.ca
}

Current Version: J a n . 14 , 2013 


\title{
The Effect of Voluntary Disclosure on Firm Risk and Firm Value: Evidence from Management Earnings Forecasts
}

\begin{abstract}
This study investigates whether the voluntary disclosure of management earnings forecasts influences investors' assessment of firm risk and firm value. We find a significant negative relationship between the issuance of management earnings forecasts and a variety of measures of firm risk (idiosyncratic risk, stock return volatility, beta, and bid-ask spreads), with more frequent, more precise and more accurate earnings forecasts further decreasing firm risk. Our results therefore suggest that information quality is an important determinant of both diversifiable risk and nondiversifiable systematic risk. We also demonstrate that management earnings forecasts are positively associated with firm value as captured by Tobin's Q while more frequent, precise and accurate forecasts further enhance valuation premiums. Finally, we find that management earnings forecasts impact firm value not only through a reduction in firm risk, but also through changing investors' perceptions about future cash flows. Our results are robust to various sensitivity checks. Overall, releasing high-quality management earnings forecasts is associated with important capital market benefits.
\end{abstract}

JEL Codes: G12, G14, G32, G34, M41

Keywords: management earnings forecasts, voluntary disclosure, firm risk, firm value, information quality 


\section{Introduction}

Capital market participants rely on a steady stream of information to assess risk and judge future prospects in order to accurately value a firm’s equity. Firm management assists in this process by providing information through a variety of channels, such as regulatory filings as well as voluntary communication with outside investors and analysts (Healy and Palepu, 2001). Forecasts related to the firm’s anticipated earnings per share (EPS) are one of the primary voluntary disclosure mechanisms through which managers can provide additional information and signals to outside stakeholders about the expected future performance of their firm. In fact, Anilowski, Feng and Skinner (2007) document that the number of firms releasing voluntary earnings guidance has increased from 10-15 percent in the 1990s to approximately 30 percent in 2004. In this study, we evaluate the economic implications of management earnings forecasts (MEFs hereafter) for U.S. firms. Specifically, we investigate how different characteristics of MEFs influence investors’ assessment of both firm risk and firm value.

Prior literature investigating the consequences of voluntary MEFs largely focuses on short-term results such as stock market reactions immediately following the issuing of the forecasts. For instance, using short-term event windows, previous work finds that MEFs influence stock price (e.g., Pownall, Wasley and Waymire, 1993) and lead to a reduction in bid-ask spreads (Coller and John, 1997). Starting to move towards a longer-term perspective, Ng, Tuna and Verdi (2008) explore how forecasting credibility moderates the under-reaction to MEF news using 3-month and 12-month hedge portfolio returns.

In another recent study, Rogers, Skinner and Buskirk (2009) go beyond looking at the stock price reaction to earnings forecasts. They examine the behavior of options prices for a sample of firms that voluntarily disclose earnings forecasts and also have exchange-traded equity options. Using an event study, they compare the implied volatilities from these options before and after the release of earnings forecasts as well as after the actual earnings announcements. The implied volatility measures are meant to capture potential changes in firm risk and investor uncertainty about firm value. They find that the forecasts are 
associated with increased short-run volatility when bad news is released, particularly if it is released on a sporadic basis, while there is only a modest decline in volatility when the news is good, especially when the firm releases news on a more regular basis.

Rogers et al. (2009) provide interesting results demonstrating how investor risk perception is impacted by earnings forecasts. Our analysis extends their work by exploring the overall effects of MEFs on both firm risk and firm value, particularly by going beyond considering short-term market reactions and treating MEFs as isolated events. While short-term market reactions can provide important information, we are interested in understanding the value relevance of management issuing earnings forecasts. According to Francis and Schipper (1999), value relevance is defined as the impact of financial information on share value. Consequently, we use Tobin's Q as our firm valuation measure because it can capture the expected changes in future cash flows and thus reflect the aggregate impact of actions by management (e.g., Lang and Stulz, 1994; Daske, Hail, Leuz and Verdi, 2008). The survey of senior managers performed by Graham, Harvey and Rajgopal (2005) found that these managers believe disclosing reliable and precise information can reduce information risk about a company's stock. Consequently, the consistent disclosure of MEFs should have tangible effects on both the apparent riskiness of a stock to investors as well as on firm value. In addition, Anilowski et al. (2007) posit that given the pervasiveness of MEFs, the aggregation of the news from MEFs provides information about the expected future cash flows of firms in general. However, none of the prior studies directly examines the overall impact of MEF strategies on both firm risk and firm value (e.g., no such studies are reported by Hirst, Koonce, and Venkataraman, 2008). We address this void and extend the existing literature by empirically testing the relationship between MEFs and firm risk as well as firm value.

Furthermore, managers face a broad array of choices regarding the release of forward-looking earnings information (King, Pownall and Waymire, 1990; Hirst et al., 2008). The first stage of our analysis focuses on the impact of a firm deciding to voluntarily issue earnings forecasts. By deciding to provide 
guidance to outside stakeholders, management appears to be making a clear statement regarding its commitment to provide investors with information beyond that required in regulatory filings. However, the decision to simply disclose such information through these forecasts may not be sufficient to impact investors' perception of firm risk or firm value. Beyond considering the issuing of forecasts, it is also important to consider characteristics of these forecasts. Having chosen to issue an earnings forecast is the first key choice, but the manager faces various choices regarding the characteristics of that forecast. These choices include the precision of the forecast (e.g., point estimate, range, open-interval or qualitative), the frequency (e.g., quarterly versus annual, or the number of forecasts), and the horizon (e.g., next quarter, next year or further). In addition, because MEFs can be verified ex post, the accuracy of the forecasts, i.e., how the forecasted earnings deviate from the actual realized earnings, is another important characteristic (Hirst et al., 2008). Our tests focus on the impact on both firm risk and firm value of four characteristics of MEFs: occurrence, frequency, precision, and accuracy. Specifically, using 23,435 firm-year observations for 4,724 firms from 1998 to 2007, we examine the effects of the above-mentioned forecast characteristics on firm risk and firm value. We adopt four proxies to measure firm risk: idiosyncratic risk, beta, total firm risk, and bidask spread. We consider a broad cross-section of risk measures because the estimation risk literature suggests that a lack of information will not only influence idiosyncratic risk, but also nondiversifiable systematic risk (Barry and Brown, 1985; Lambert et al., 2007). Our proxy for firm value is Tobin’s Q, which is based on an investor's assessment of the present value of anticipated future cash flows (e.g., see Lang and Stulz, 1994), and is a common valuation measure in the literature to capture long-term valuation effects (e.g., see Doige, Karolyi and Stulz, 2004; Brown and Caylor, 2006; Kohlbeck and Mayhew, 2010; Al-Akra and Ali, 2012) rather than short-term market reactions to specific events.

Briefly, our results reveal the following. First, as predicted, our cross-sectional tests indicate that firms disclosing MEFs exhibit lower idiosyncratic risk, systematic risk (i.e., beta), total firm risk and bid-ask spreads compared to firms not releasing forecasts. In addition, the characteristics of these forecasts also help 
explain investors' perceptions about firm risk. Firms releasing more frequent, precise, or accurate MEFs are also associated with reduced idiosyncratic risk, systematic risk, total firm risk and bid-ask spreads. Collectively, our results on firm risk present consistent evidence that information quality, as proxied by the multiple characteristics of MEFs, has a significant impact on the market's assessment of idiosyncratic risk, systematic risk, and information risk of our sample firms.

We also investigate the effects of MEFs on firm value (Tobin's Q). We find consistent evidence that forecast occurrence, frequency, precision and accuracy are positively related to firm valuation (Tobin’s Q) indicating that the aggregate impact of forecasting strategies on firm value is clearly positive. In addition, disclosure impacts firm valuation through two mechanisms: reducing firm risk or changing expected future cash flows (Lang, Lins and Miller, 2003). Although we find consistent evidence that releasing MEFs is negatively associated with firm risk, it is initially not clear whether the impact of voluntary disclosure of MEFs on firm value is a result of the change in firm risk or in expected future cash flows. To explore this question, we control for risk measures in our firm valuation models. If, after controlling for firm risk, MEFs continue to be significantly related to firm valuation, it is reasonable to conjecture that the incremental effect on valuation comes from changes in expected cash flow. Empirically, we provide evidence to support this conjecture, which suggests that firms' forecasting strategies also influence their expected future cash flows. To determine the nature of this relationship, we adopt several approaches to examining the concern of potential causality and the possible endogeneity between various firm-specific characteristics and the voluntary issuing of different types of MEFs. Specifically, we repeat our analysis using firm-fixed effect models, Granger Lead-Lag models, Heckman two-stage models and propensity score matching (PSM) method to control for endogeneity issues. Our results are robust to all these approaches.

Our work contributes to the literature on the effects of information quality on firm risk. As pointed out by Gordon, Loeb and Tseng (2009), risk management is a fundamental issue in today's fast-changing business environment because it influences the interaction between firms and stakeholders with respect to 
capital allocation choices. However, the associations between accounting information quality, idiosyncratic risk as well as systematic risk have been largely overlooked (Ashbaugh-Skaife et al., 2009; Rajgopal and Venkatachalam, 2010). Recently, a new stream of literature has emerged to investigate the impact of information quality on both idiosyncratic risk and systematic risk (Lambert et al., 2007; Ashbaugh-Skaife et al., 2009). More specifically, Lambert et al. (2007) model the direct and indirect effects of information quality on the cost of capital and they show that the quality of information not only influences market's assessment of the variance of a firm's cash flows (i.e., idiosyncratic risk) but also the assessed covariance with other firms' cash flows (i.e., systematic risk). By concurrently examining the impact of MEFs on various firm risk measures, our research adds a new perspective to this literature.

Our research design offers an important advantage to gauge the impact of information quality relative to other measures of disclosure quality used in the literature. Previous studies use aggregate or subjective metrics (Welker, 1995; Botosan, 1997), so MEFs provide a unique setting - they are a less uncertain measure of information quality as they can be validated when the actual realized earnings are released. Our findings that MEFs impact both idiosyncratic risk and beta support the theoretical work by Lambert et al. (2007). Specifically, our results suggest that information quality is an important determinant of both idiosyncratic risk and nondiversifiable systematic risk which will ultimately be impounded in the market's assessment of firm value. Understanding how to identify each of these risks is becoming increasingly important as related literature in finance demonstrates that idiosyncratic risk has increased substantially over the last four decades (Campbell et al., 2001). Our evidence that information quality is associated with idiosyncratic risk is thus useful to policymakers, firm managers and investors.

Our research also makes two contributions to the literature on disclosure. First, we contribute to the literature on MEFs. Distinct from prior studies that focus on short-term stock market reactions using eventstudy approaches (e.g., Pownall et al., 1993 and Coller and John, 1997), we assess the importance of MEFs on both firm risk and firm value. In addition, managers have great discretion and control over forecast 
characteristics, yet only nascent understanding exists regarding the impact on markets of issuing forecasts with different characteristics (Hirst et al., 2008). By focusing on four key forecast characteristics, we advance the literature by adding evidence on the aggregate economic implications of these multidimensional characteristics. Managers may benefit from our research because they can better understand the choices they make related to their earnings forecasts and how they may as a result garner desirable benefits from market participants. Regulators and investors may benefit by better understanding the benefits of different types of disclosure.

Second, our work extends the literature on the association between disclosure and the cost of capital. Although theoretical work suggests that voluntary disclosure leads to a reduction in the cost of capital, empirical results are mixed and consensus has not been reached (Botosan, 2006). For example, Botosan (1997) indicates that improved disclosure is related to a decrease in the cost of capital only when analyst following is low. Kim and Shi (2011) explore the impact of MEFs on the cost of capital and find that firms forecasting bad-news actually experience a significant increase in their cost of capital after disclosing MEFs. Botosan (2006) maintains that one plausible reason for the mixed results in the literature is because researchers use different measures for the cost of capital. By adopting four risk measures to directly measure firm uncertainty, our study adds to the debate on this line of research.

The paper is organized as follows. Section 2 reviews the relevant literature and presents a development of our hypotheses. Section 3 describes the data as well as our empirical models. Results are presented in section 4 and section 5 reports our robustness checks. Finally, section 6 presents a summary and conclusions.

\section{Literature Review and Hypotheses Development}

Lack of information about firms and their securities can affect firm risk and value through several channels. Our work first builds on the estimation risk literature (Klein and Bawa, 1976; Barry and Brown, 
1985, 1986; Lambert et al., 2007). Barry and Brown (1985) develop a model of differential information in which the amount of information available differs across securities. They show that investors demand a risk premium for the lack of information, and this information risk is nondiversifiable, so it affects the systematic risk of securities, as measured by betas or covariances. Along the same line, recent theoretical work by Lambert et al. (2007) models the direct and indirect effects of accounting information quality on the cost of equity in a multi-security Capital Asset Pricing Model (CAPM) setting and concludes that information risk increases market participants' estimation of the variance of a firm's cash flow (i.e., idiosyncratic risk) and covariances with other firms’ cash flows (i.e., systematic risk). Empirically, Ashbaugh-Skaife et al. (2009) reveal that firms that disclose internal control deficiencies have significantly higher idiosyncratic risk, systematic risk (beta) and cost of equity. Rajgopal and Venkatachalam (2010) find that better quality accounting information is associated with lower idiosyncratic volatility.

Our work also draws on prior studies that link disclosure to liquidity and the cost of capital (e.g., Diamond and Verrecchia, 1991; Leuz and Verrecchia, 2000; O’ Hara, 2003; Easley and O’Hara, 2004). This line of research maintains that voluntary disclosure reduces the information asymmetry between uninformed and informed investors, and thus increases a firm’s liquidity and decreases a firm’s cost of capital. O’Hara (2003) asserts that liquidity can affect the risk of holding an asset, and Merton (1987) shows that in equilibrium the value of a firm is always lower when there is incomplete information. Empirical work generally substantiates this stream of theory (e.g., Botosan, 1997; Welker, 1995). Therefore, it is reasonable to grant that voluntary disclosure may reduce firm risk and enhance firm value through the mechanism that increases liquidity.

Managers choose to issue forward-looking earnings forecasts to reduce information asymmetry between managers, analysts and investors (Ajinkya and Gift, 1984; Coller and Yohn, 1997; Healy and Palepu, 2001). As argued above, lowering information asymmetry is viewed as desirable because it is associated with lower estimation risk, higher liquidity and lower cost of capital. Ultimately, the voluntary 
disclosure of MEFs can lower uncertainties related to a firm’s future prospects. Further, previous studies show that enhanced disclosure and governance practice can improve firm value (Brown and Caylor, 2006; Kohlbeck and Mayhew, 2010; Al-Akra and Ali, 2012). For instance, Brown and Caylor (2006) show that some corporate governance provisions are positively associated with firm value. Disclosure may influence firm value through two mechanisms: an impact through firm risk and another impact through expected future cash flows (Lang, Lins and Miller, 2003; Al-Akra and Ali, 2012). Existing literature posits that MEFs provide important information about expected future cash flows of individual firms (Ajinkya and Gift, 1984; Anilowski et al., 2007). Therefore, it is reasonable to conjecture that voluntary disclosure of MEFs enhances firm value through reducing firm risk and/or changing expected future cash flow.

We employ multiple measures to capture the uncertainty or riskiness associated with a firm by using characteristics of the firm's share price, such as idiosyncratic stock volatility, systematic risk, overall stock return volatility, and bid-ask spreads. Given that idiosyncratic risk is diversifiable, the implications drawn from better understanding the association between information quality and idiosyncratic risk can help investors improve their diversification strategies (Rajgopal and Venkatachalam, 2010). Systematic risk is also relevant here because the average pricing effect of information cannot be diversified when firms’ cash flows are correlated (Lambert et al., 2007). As for overall stock return volatility (i.e., total risk), it has an idiosyncratic component as well as a systematic component and thus affects the utility of stockholders and other stakeholders (Sorescu and Spanjol, 2008). Finally, we also focus on bid-ask spread because it captures the risk associated with information asymmetry (Coller and Yohn, 1997).

We use Tobin’s Q to proxy for firm value. As discussed above, Tobin’s Q is a common valuation measure in the literature to capture long-term effects (e.g., see Doige et al., 2004; Brown and Caylor, 2006; Kohlbeck and Mayhew, 2010; Al-Akra and Ali, 2012) rather than short-term market reactions to specific events. Taking all the above reasoning together, we advance our first hypothesis: 
Hypothesis $\mathbf{H}_{\mathbf{1}}$ : Firms that release voluntary earnings forecasts are associated with lower firm risk (as captured by overall stock return volatility as well as idiosyncratic stock volatility, beta, and bidask spreads).

Hypothesis $\mathbf{H}_{\mathbf{1 b}}$ : Firms that release voluntary earnings forecasts are associated with an enhanced firm valuation (as captured by Tobin’s Q).

Other characteristics of MEFs (beyond the decision to issue MEFs) may also impact firm risk and firm value. In the first hypothesis, disclosure occurrence is an important aspect of a firm's overall disclosure strategy; but so is the disclosure frequency. Prior research shows that there are large variations in how frequently firms choose to release earnings forecasts (Rogers and Stocken, 2005). The forecast frequency has also been found to depend on various factors. For example, Waymire (1985) shows that firms disclosing more frequent forecasts are associated with lower earnings volatility. Graham et al. (2005) posit that forecast frequency is related to the firm's probability of meeting or beating earnings benchmarks.

The above evidence suggests that the frequency at which a firm chooses to issue forecasts may be associated with the firm manager's uncertainty about future cash flows (i.e., firm risks or other firm-specific antecedents). Furthermore, Easley and O’Hara (2004) demonstrate that the quantity of information affects asset prices through reducing systematic risk. Economic theory also predicts that commitment to persistent disclosure reduces the information risk of a firm, and thus reduces the cost of capital and enhances firm valuation (Diamond and Verrecchia, 1991; Leuz and Verrecchia, 2000). Empirically, Botosan and Harris (2000) find that managers normally signal their commitment to disclosure by providing disclosures more frequently. Increasing disclosure frequency can improve both the content and the timeliness of the information. Therefore, by providing earnings forecasts more frequently, management may supply more pertinent information to the market and the information revealed is timelier for the investors' decisions. All 
these benefits should result in a decrease in the risk or uncertainty of future cash flows. This leads to our second hypothesis:

Hypothesis $\mathbf{H}_{2 \mathbf{a}}$ : Firms releasing more frequent earnings forecasts are associated with a greater reduction in firm risk.

Hypothesis $\mathbf{H}_{2 \mathbf{b}}$ : Firms releasing more frequent earnings forecasts are associated with a greater enhancement in firm valuation.

Another important characteristic of MEFs is their precision: point forecasts, specific ranges (i.e., of a closed-interval nature), open-interval ranges (i.e., minimums or maximums), and of a qualitative nature (i.e., providing general impressions about the firm’s earnings prospects). ${ }^{1}$ Ajinkya, Bhojraj and Sengupta (2005) indicate that 78 percent of their sample firms during the period 1997-2002 release point or specific range forecasts. Empirical studies suggest that forecast precision captures managers’ beliefs about future cash flow (King et al., 1990) and that, in essence, more precise forecasts are viewed as indicating greater managerial certainty and ability (Hughes and Pae, 2004). In addition, MEFs with different precisions have different information content and rational investors may discount qualitative earnings projections (Pownall et al., 1993). Using short-term event studies, prior studies provide evidence that management forecast precision affects the beliefs of investors and financial analysts. For example, Baginski, Conrad, and Hassell (1993) examine the effects of information precision on short-term equity pricing, and they support a positive relation between forecast precision and the importance of forecasts on security prices.

Theoretical work suggests that a signal's precision is important in belief development (Kim and Verrecchia, 1991a, 1991b). Specifically, Kim and Verrecchia (1991b) examine a two-period rational expectations model whereby traders are assumed to be differentially informed and vary in the precision of

\footnotetext{
${ }^{1}$ Point estimates are those whereby a specific estimate is disclosed such as "Earnings will be X this period.” Range estimates are closed-interval forecasts of the form "Earnings will be between X1 and X2 this period." Open-interval estimates are lower or upper bound forecasts of earnings. A minimum estimate is in the form "Earnings will be greater than X1 this period" whereas a maximum estimate is disclosed such as "Earnings will be no more than X2 this period.” Qualitative estimates are general impressions in the form "Earnings will be favorable this year compared with last year.”
} 
their private prior information. They find that the price reaction to the unexpected portion of a disclosure is an increasing function of its relative importance across the posterior beliefs of traders. The relative importance is positively related to the precision of the announcement and inversely related to the precision of preannouncement information. The study by Kim and Verrecchia (1991b) implies that the price reaction to the public information is a positive function of the information's precision. Moreover, Kim and Verrecchia (1994) show that as the precision of public information increases, liquidity increases. This suggests that a firm can benefit by providing improved disclosure. Easley and O’Hara (2004) also imply that firms can influence their cost of capital by selecting the precision of information it reveals to investors. Building on this line of research, we expect that consistent disclosure of precise forecasts will have a positive effect on firm risk and valuation. Thus, we present our third hypothesis:

Hypothesis $\mathbf{H}_{3 \mathbf{a}}$ : Firms disclosing more precise earnings forecasts are associated with a greater reduction in firm risk.

Hypothesis $\mathbf{H}_{3 \mathbf{b}}$ : Firms disclosing more precise earnings forecasts are associated with a greater enhancement in firm valuation.

The accuracy of the forecast is another characteristic that may influence the economic consequences of the forecast. Managers may have incentives to issue self-serving forecasts and thus not all MEFs are accurate as measured by the difference between actual and forecasted earnings (Hutton and Stocken, 2009; and Hirst et al., 2008). However, studies find that only accurate information will enhance the resource allocation in capital markets and reduce uncertainties related to the future prospects of a firm (Healy and Palepu, 2001). Prior studies document that forecast accuracy influences how analysts react to a forecast. For example, Williams (1996) finds that analysts revise their forecasts more for firms with high prior forecasting accuracy. In recent studies, Hutton and Stocken (2009) and Ng et al. (2008) show that when a firm released accurate information in previous periods, investors respond more to current MEF news. In 
addition, CFOs surveyed by Graham et al. (2005) believe that more accurate voluntary disclosure helps to eliminate the information risk of a firm, and potentially reduce the risk premium that investors require. Rogers and Stocken (2005) advance that investors adjust their valuation of a firm according to the credibility of the MEFs and firms may suffer from a "liar’s discount" when their voluntary disclosure is proven to be deceptive. Taken as a whole, we predict that if firms consistently provide accurate voluntary earnings forecasts (i.e., the forecasted earnings are relatively close to the actual earnings), they will benefit from reducing uncertainty about their future prospects. This reasoning leads to our fourth hypothesis:

Hypothesis $\mathbf{H}_{4 \mathbf{a}}$ : Firms releasing more accurate earnings forecasts are associated with a greater reduction in firm risk.

Hypothesis $\mathbf{H}_{\mathbf{4}}$ : Firms releasing more accurate earnings forecasts are associated with a greater enhancement in firm valuation.

\section{Data and Empirical Model}

\subsection{Sample Selection and Data Source}

We create our sample by merging Compustat files (accounting data), CRSP (stock price data), and the First Call Corporate Investor Guideline (CIG) database (MEF data) and Analyst Forecast dataset (analyst coverage data) over the period from 1998 to 2007. The above procedure results in a final sample of 23,435 firm-year observations for 4,724 firms. We focus on the post-1998 period because previous studies find that the CIG database appears to be incomplete prior to 1998 (Anilowski et al., 2007). The CIG database has been utilized by a number of researchers in accounting to investigate a variety of research questions (e.g., Ajinkya et al., 2005; Rogers and Stocken, 2005; Anilowski et al., 2007; Rogers et al., 2009). In our study, we focus on EPS forecasts as these are the most common form of forecast and the most anticipated by analysts. Consequently, EPS forecasts are the most logical forecasts to consider and focusing on only one type of forecast allows us to have a "clean" data set, so we eliminate non-EPS forecasts and earnings pre- 
announcements released after the end of fiscal period. The CIG database carries both annual and quarterly forecasts. For our primary tests we focus on annual forecasts. This is consistent with the arguments in Hutton and Stocken (2009) where the significance of forecasting accuracy and reputation is enhanced by an increase in the horizon of a forecast, so annual forecasts offer a more powerful setting for exploring the influences of forecast accuracy than quarterly forecasts. ${ }^{2}$

A breakdown of MEF observations is presented in Table 1. Among our total sample of 23,435 firmyear observations, 7,603 (32.4\%) are defined as forecasters, i.e., firms releasing annual MEFs. Among the 7,603 forecasting observations, $40.1 \%$ of the firms provide more than five forecasts during the sample period. Point forecasts account for $19.6 \%$ of our sample, whereas range forecasts account for $66.9 \%$ and the remaining $13.5 \%$ are either open-interval or qualitative forecasts.

\section{[Insert Table 1 Here]}

\subsection{Tests on Firm Risk}

To test our hypotheses on firm risk, we rely on four risk measures that are standard in the finance and accounting literature: (i) idiosyncratic or firm-specific risk (e.g., Goyal and Santa-Clara, 2003), (ii) stock return volatility (e.g., Guay, 1999), (iii) beta or market risk (e.g., Guay, 1999), and (iv) bid-ask spreads on quoted share prices (e.g., Coller and Yohn, 1997). The calculation and motivation for the first three measures are described below in more detail. The spreads are calculated as the average of the end of month closing bid and ask prices. The bid-ask spread is viewed as a proxy for market liquidity and the asymmetry of information (See Welker, 1995).

We estimate the idiosyncratic or firm-specific risk as well as beta from the following regression of excess stock returns on the market risk premium:

$$
\mathrm{R}_{\mathrm{i}, \mathrm{t}}-\mathrm{R}_{\mathrm{f}, \mathrm{t}}=\alpha_{\mathrm{i}}+\beta_{\mathrm{i}}\left(\mathrm{R}_{\mathrm{m}, \mathrm{t}}-\mathrm{R}_{\mathrm{f}, \mathrm{t}}\right)+\varepsilon_{\mathrm{i}, \mathrm{t}}, \quad \mathrm{i}=1, \ldots, \mathrm{N} \text { and } \mathrm{t}=1, \ldots, \mathrm{T}
$$

\footnotetext{
${ }^{2}$ We use both quarterly and annual forecasts in our robustness checks, and the results are similar.
} 
where $R_{i, t}$ is the monthly stock return for firm $i$ in month $t, R_{f, t}$ is the monthly return from holding a 30-day risk-free treasury-bill provided by CRSP, $\mathrm{R}_{\mathrm{m}, \mathrm{t}}$ is the monthly return from the CRSP value-weighted market index, $\alpha_{\mathrm{i}}$ (or alpha) is the intercept term, $\beta_{\mathrm{i}}$ (or beta) is the slope coefficient, and $\varepsilon_{\mathrm{i}, \mathrm{t}}$ is an error term. We run this regression for each firm in our sample. The idiosyncratic risk is the standard deviation of the residuals from the regression using model (1). The volatility is the annualized monthly standard deviation of each firm's return series.

We then estimate ordinary least square (OLS) models to test the effects of MEFs on firm risk using the following model:

$$
\text { Risk }_{\mathrm{i}, \mathrm{t}}=\mathrm{a}+\mathrm{b} \mathrm{D}_{\mathrm{MEF}, \mathrm{i}, \mathrm{t}}+\Sigma \gamma \mathrm{F}_{\mathrm{k}, \mathrm{i}, \mathrm{t}}+\mathrm{e}_{\mathrm{i}, \mathrm{t}} \quad \mathrm{i}=1, \ldots, \mathrm{N} \text { and } \mathrm{t}=1, \ldots, \mathrm{T}
$$

We follow the literature (e.g., Ajinkya et al., 2005) to define $D_{M E F, i, t}$ to refer to one of the four characteristics of MEFs (depending on which of our four hypotheses is being tested): (i) for H1, it represents the occurrence of MEFs, i.e., takes on a value of 1 when a firm releases MEFs, and 0 otherwise; (ii) for H2, it denotes the log transformation of the total number of forecasts issued by a firm in the sample period;(iii) for H3, it stands for the log transformation of an ordinal variable that takes a value of four for point forecasts, three for range forecasts, two for an open-interval forecasts, one for a qualitative forecasts, and zero for non-forecasters; (iv) for H4, it means the error of MEFs, i.e., the absolute value of the difference between the forecasted earnings and the actual realized earnings scaled by the beginning-of-period stock price. Consistent with our hypotheses, we predict that forecast occurrence, frequency and precision are negatively associated with firm risk and positively associated with firm value. However, since forecast accuracy is the inverse of forecast error, we predict that forecast error is positively associated with firm risk measures and negatively associated with firm value.

Our control variables, $F_{k}$, are motivated from the existing literature and are described as follows (note that the i,t subscript is suppressed but each variable is measured on a firm-year basis). SIZE represents the log of the market value of equity as of the firm's fiscal year-end. Since larger firms tend to be less risky, we 
expect the coefficient to be negative. LEVERAGE is the ratio of total liabilities to total assets measured at the fiscal year-end. Since firms with more leverage tend to be riskier, we expect the coefficient to be positive. INTANGIBLE is the ratio of total value of intangible assets to total assets measured at the fiscal year-end. The variable captures the degree of information asymmetry - more intangible assets imply there is more intellectual capital and thus assets which are harder to value by investors. Firms with more intangible assets will have a higher degree of information asymmetry so we expect the coefficient to be positive. GROWTH is the percentage increase in sales over the past 3 years. The variable captures the firm's future prospects assuming that larger growth indicates increased future prospects. We expect firms which are growing more rapidly to have a higher degree of information asymmetry so we expect the coefficient to be positive. LOSS is an indicator variable which takes on the value of one if the firm reports a loss in the current period, and zero otherwise. Prior research shows that uncertainty is higher when a firm has a loss (Kim and Shi, 2011); therefore, we expect a positive coefficient for this variable. DIVIDEND is the dividend yield calculated as dividend per share divided by earnings per share. Firms paying more dividends are normally mature firms with lower risk (Ashbaugh-Skaife et al., 2009), so we predict a negative coefficient on this variable. We also include YEAR and INDUSTRY dummies, not reported in the tables. We use a series of ten industry classifications based on the standard break-down according to two-digit SIC codes. Specifically, we define the industries as agriculture/forestry/fishing, mining, construction, manufacturing, transportation, wholesale trade, retail trade, finance/insurance/real estate, services and other.

\subsection{Tests on Firm Value}

In our tests of the hypotheses related to firm value, we measure firm value using Tobin’s Q. ${ }^{3}$ Tobin’s $\mathrm{Q}$ is computed as the market value of equity plus the book value of the total liabilities in the numerator and

\footnotetext{
3 Note: we also considered other measures for firm value including the market-to-book ratio and alpha from the CAPM but found that they did not provide any further insights beyond the more commonly considered Tobin's Q. Consequently, these results are not presented.
} 
book value of assets in the denominator using the data from the firm's fiscal year end obtained from Compustat. Using Tobin's Q, we employ OLS to estimate our models and formally evaluate its relationship with the voluntary disclosure of MEFs while controlling for other factors believed to influence firm value:

$$
\text { Tobin's } \mathrm{Q}_{\mathrm{i}, \mathrm{t}}=\mathrm{a},+\mathrm{b} \mathrm{D}_{\mathrm{MEF}, \mathrm{i}, \mathrm{t}}+\sum \gamma \mathrm{F}_{\mathrm{k}, \mathrm{i}, \mathrm{t}}+\mathrm{e}_{\mathrm{i}, \mathrm{t}} \quad \mathrm{i}=1, \ldots, \mathrm{N} \text { and } \mathrm{t}=1, \ldots, \mathrm{T}
$$

where $\mathrm{D}_{\mathrm{MEF}, \mathrm{i}, \mathrm{t}}$ are the same as those used in equation (2). For the control variables, $\mathrm{F}_{\mathrm{k}, \mathrm{i}, \mathrm{t}}$, we include $\boldsymbol{S I Z E}$, LEVERAGE, GROWTH, YEAR and INDUSTRY dummies as before but also include ROA and ANALYST. $\boldsymbol{R O A}$ (return on assets) is calculated as the operating income divided by the total assets as of the firm's fiscal year-end. It is expected that firms with higher profitability will have higher value. ${ }^{4} \boldsymbol{A N A L Y S T}$ is the number of analysts following a firm. Previous studies (e.g., Lang et al., 2003) show that firms with higher analyst coverage are associated with higher firm valuation, so we predict a positive sign for this variable.

\section{Results}

Before formally testing our hypotheses, we examine our data. In Table 2 we present some summary statistics. As mentioned earlier, our data set contains 23,435 firm-year observations for 4,724 U.S. firms over the period from 1998 to 2007. We find that our firms represent a broad cross-section of the U.S. market. Our set of firms ranges from very small firms to very large firms (average market capitalization of $\$ 3,940$ million with the 25th and 75th percentiles being \$153 million and \$1,807 million respectively), and from very profitable to less profitable (with a median annual return on assets of $2.6 \%$ over our sample period and an interquartile range from $-0.2 \%$ to $7 \%$ per annum) over all industries. Median liability-to-assets is $54.8 \%$. Median aggregate 3-year sales growth is 30.8\%. Median beta is 1.051, and median Tobin's Q is 1.409, which are comparable to the data in other studies (Ashbaugh-Skaife et al., 2009; Kohlbeck and Mayhew,

\footnotetext{
${ }^{4}$ We also perform additional sensitivity checks following previous literature (e.g., Lang and Stulz, 1994; Durnev and Kim, 2004) by controlling for: 1) R\&D expenses (deflated by total assets) in our Tobin's Q model; and 2) dividend yield . Our results are not sensitive to these corrections. However, adding these control variables substantially reduced our sample size, and thus these results are unreported.
} 
2010). To mitigate potential concerns associated with extreme values, we winsorize the bottom $1 \%$ and top $1 \%$ of the variables ${ }^{5}$.

\section{[Insert Table 2 Here]}

To test our hypotheses, we start by using the models in equations (2) and (3) above. Tables 3a we presents the results from the estimation on the role played by voluntary MEFs in explaining firm risks (equation (2) model), while Table 3b summarize the results on the impact of MEFs on firm valuation (equation (3) model). In Table 3a we see that the level of a firm's idiosyncratic risk, stock return volatility, beta, and bid-ask spread decrease when firms voluntarily issue MEFs - the estimated coefficients on MEF are significantly negative in all four models as we predicted in $\mathrm{H}_{\mathrm{a}}$. Although not the focus of our analysis, we find that smaller firms, firms incurring a loss and firms with higher growth are associated with higher risk consistent with prior studies (Guay, 1999; Ashbaugh-Skaife et al., 2009). In addition, similar to Ashbaugn-Skaife et al. (2009), we find the surprising result that highly levered firms are associated with lower firm risk.

In Table 3b we present the results from the estimation of model (3). Our measure of firm value is Tobin's Q, a measure which provides a broad, aggregate perspective on how investors are valuing a firm. It measures the entire value of the firm (i.e., its enterprise value) relative to the assets that it employs so an increase in this value is related to an increase in how investors are valuing the firm. We present five models here. The first model does not control for risk measures, so we can only infer whether MEFs impact firm value. The second to the fifth model control for different risk measures, i.e., idiosyncratic risk, total risk as measured by stock return volatility, beta and bid-ask spread respectively. As discussed earlier, the influence of voluntary disclosure on firm value could either come from changes in firm risk or from changes in expected future cash flows. Therefore, we estimate models controlling for risk which allows us to isolate the

\footnotetext{
${ }^{5}$ To address outlier issue, it is standard to winsorize variables (normally at 1\%) in the accounting and finance literature (Ajinkya et al., 2005; Durnev and Kim, 2005).
} 
effects of changes in firm risk on firm valuation and draw implications on whether MEFs affect firm value through changes in risk or expected future cash flows. In the first model without measures of firm risk, the coefficient on MEF is positive and significant, which is consistent with $\mathrm{H}_{\mathrm{b}}$ and suggests that releasing $\mathrm{MEF}$ has a positive effect on firm valuation. Moreover, in the models controlling for firm risks, the coefficients on MEF continue to be positively significant, which implies that disclosing MEF also affects firm value through changes in expected future cash flows. Our results are consistent with prior studies such as Lambert et al. (2007) who suggests that disclosure can change investors' expectations on future cash flow or even influence a firm’s real business decisions which will ultimately change future cash flows.

[Insert Tables 3a and 3b Here]

We also investigate the possible influence of other forecast characteristics on firm risks and valuation. Table 4 presents the results on how frequency of MEFs influences firm risk and valuation. Table 4a presents the results on firm risk while Table $4 \mathrm{~b}$ demonstrates the results on firm value. In Table 4a, the coefficients on forecast frequency are negative and significant across all four models. This is consistent with $\mathrm{H} 2_{\mathrm{a}}$ and implies that firms issuing more frequent forecasts are associated with lower idiosyncratic risk, systematic risk, total risk and bid-ask spread.

Results in Table 4b are consistent with our hypothesis $\mathrm{H}_{2} \mathrm{~b}$. In all five models, whether controlling for risk measures or not, the coefficients on forecast frequency are all positive and significant, which implies that firms releasing more frequent MEFs are associated with higher firm valuation. The significant results after controlling for risk measures suggest that releasing frequent MEFs influence firm valuation through two mechanisms: changes in firm risk as well as changes in the expected future cash flows.

[Insert Tables 4a and 4b Here]

Tables 5a and 5b present the results using the precision of MEFs. In Table 5a, we show results related to firm risk. The coefficients on forecast precision for our measures of risk are consistent with our $\mathrm{H}_{3 a}$ that firms releasing more precise information are associated with lower risk. The decrease in risk is 
statistically significant for all risk measures, i.e., idiosyncratic risk, systematic risk, total risk and bid-ask spread. Table 5b presents the results for firm value. The estimated coefficients on forecast precision are all positive and significant. The results clearly indicate that firms making more precise forecasts are associated with an increase in firm valuation. This provides strong support for our hypothesis $\mathrm{H}_{3 \mathrm{~b}}$. It appears that the precision of the estimates provides more information content and thus impacts the perceived level of risk for a firm and how investors value the firm.

\section{[Insert Tables 5a and 5b Here]}

The effects of the accuracy of MEFs on firm risk and firm valuation are presented in Tables 6a and 6b. As explained earlier, our empirical proxy is forecast error, which is the inverse of forecast accuracy, so we predict that the coefficients of forecast error are positive in the firm risk models whereas the coefficients are negative in the firm valuation models. Table 6a summarizes the results on firm risk. The coefficients on forecast error are positive and significant in the models with idiosyncratic risk, stock return volatility and beta, but the coefficient in the average spread model is insignificant. Taken as a whole, firms release more accurate MEFs are associated with lower idiosyncratic risk, systematic risk, and total risk consistent with our $\mathrm{H} 4_{\mathrm{a}}$. Table $6 \mathrm{~b}$ presents the results on firm value. In all five models, the coefficients on forecast error are negative and significant, which suggests that firms with higher forecast errors are related to lower firm valuation. Put differently, we find that firms releasing more accurate MEFs are associated with a greater enhancement in firm valuation, which is consistent with $\mathrm{H}_{4}$.

\section{[Insert Tables 6a and 6b Here]}

Taken together, our findings suggest that releasing MEFs provide great benefits in reducing firm risk and enhancing firm valuation, while more frequent, precise and accurate forecasts further strengthen the above benefits. Our results also imply that voluntary disclosure impacts firm valuation through two channels: i.e., changes in firm risk and changes in expected future cash flows. This finding substantiates the 
view in Lambert et al. (2007) that information quality can have an indirect effect on the cost of equity capital by changing firms' real decisions. Once the managers of a firm have built up a forecasting reputation of accuracy, its forecasting system can play a positive role in shaping its internal budgeting system and corporate governance. In addition, to protect the reputation of the firm, managers would try to avoid managerial myopia, which may lead to better investment decisions. Consequently, forecasting practices change firms’ future cash flows, not just through the perceptions of cash flows by investors, but through real decisions which help better allocate capitals.

\section{Robustness Checks}

A challenge for research on disclosure is assessing causality (Ajinkya et al., 2005). It is possible that firms with lower risk or higher Tobin's Q are more likely to release MEFs (a reverse causality issue). In addition, disclosing management earnings forecasts is discretionary and thus may depend on the same factors included in our tests on firm risk and firm value (an endogeneity issue and/or a self-selection issue). We employ several methods to provide assurance that our results are not driven by endogeneity, reverse causality or self-selection bias. First, we estimate firm-fixed effect models to exclude the possibility that our results only reflect cross-firm differences in disclosure practices. More specifically, if it were the case that some firms are inherently more likely to release MEFs, the relationships between MEF characteristics and firm risk or firm value should not be obvious in a within-firm comparison. Our untabulated results show that our primary findings, i.e., MEF characteristics are negatively associated with firm risk while positively associated with firm value, continue to hold in all firm-fixed effect models, implying that within-firm variations also explain our main results.

Second, we follow the method used by Ajinkya et al. (2005) and estimate a Granger lead-lag model by including lagged risk measures and lagged Tobin's Q while maintaining all other control variables in model (2) and (3). Our untabulated results indicate that even after controlling for lagged risk measures and 
lagged Tobin's Q, the occurrence, frequency, precision and accuracy of MEFs are still negatively related to firm risk while positively relating to Tobin’s Q, which lends further credence to our primary findings.

Third, we use the Heckman two-step model (Heckman, 1979) to control for self-selection bias. With the Heckman model, the first stage of the model investigates how different factors influence the likelihood that a firm will voluntarily issue management earnings forecasts. ${ }^{6}$ In the second stage, the estimated likelihood that a firm will voluntarily issue such guidance is inserted into the model to offset both the discrete nature of issuing management earnings forecasts (i.e., a firm either does or does not issue them) and the factors which may influence that decision and therefore may also influence the measures of firm risk and valuation. For brevity, we do not tabulate the results. However, our main results are not sensitive to this correction.

Finally, previous studies assert that for Heckman two-stage model, it is difficult to find good instruments for the first-stage model that are not correlated with the second-stage error term (Larcker and Rusticus, 2010). However, the propensity score matching (PSM) method can alleviate this concern. Following previous research using the PSM approach (Bartram, Brown and Conrad, 2011; Kim and Shi, 2012), we construct a matched sample using the predicted likelihood (called the propensity score) of releasing MEFs. To do this, we first identify a control sample of firms that have never released MEFs in our sample period. We then match forecasters to these non-forecasters using the propensity score obtained from the first-stage model we have explained in footnote (6). The advantage of PSM approach is that researchers are not required to find valid exogenous instruments in the first stage model that can be excluded from the

\footnotetext{
${ }^{6}$ Following previous literature, the dependent variable in the first-stage model is MEF, and the independent variables are SIZE, ANALYST, DISFORECAST, GOOD_NEWS, LOSS, SURPRISE, REG_FD and LITIGATE. The first variable is SIZE (as defined above). ANALYST is the number of analysts following the firm. Following prior studies (e.g., Ajinkya et al., 2005), we expect the coefficient to be positive. GOOD NEWS is a dummy variable taking on a value of one if the firm's earnings per share have increased from last year to this year. Previous literature (e.g., Skinner, 1994) documents that firms are more likely to release earnings forecasts to mitigate litigation costs when facing bad news, so we predict a negative coefficient on this variable. LOSS is as defined above. It is possible that management's ability to forecast earnings be constrained when firms making losses, so we expect the coefficient to be negative (Ajinkya et al., 2005). SURPRISE is the absolute value of the differences between the current period's and previous period's earnings per share deflated by the share price at the current fiscal year-end. $\boldsymbol{R E G} \_\boldsymbol{F D}$ takes on the value of 1 post- Regulation FD period (after October, 2000), and 0 otherwise. LITIGATE refers to industries with higher litigation risks, i.e., 1 for all firms in the biotechnology (2833-2836 and 8731-8734), computers (3570-3577 and 7370-7374), electronics (36003674), and retail industry (5200-5961), 0 otherwise (Ajinkya et al., 2005). We expect a positive coefficient on LITIGATE.
} 
second stage model. We use a maximum allowable range of propensity score of $0.1 \%$ to match our two groups. The PSM process leads to 14,806 firm-year observations with both forecasters and non-forecasters. ${ }^{7}$ Using the PSM sample, we then re-estimated model (2) and (3) and present our results in Tables 7a and 7b. As show in both tables, the PSM results are essentially identical to our primary results reported in Tables 3a and 3b. Overall, our robustness checks suggest that our main results are robust to different corrections of potential self-selection bias and endogeneity.

\section{[Insert Tables 7a and 7b Here]}

\section{Summary and Conclusions}

In this paper, we study the economic consequences of MEFs using a large sample of firms for the period from 1998 to 2007. More specifically, we explore the effects of multiple MEF characteristics (i.e., occurrence, frequency, precision, and accuracy) on both firm risk and firm value. We employ four different measures to capture firm risk, i.e., idiosyncratic risk, beta, total risk, and bid-ask spread. Compared to firms that do not issue MEFs, we find that forecasting firms have lower idiosyncratic risk, market risk (beta), total risk, and bid-ask spread. These results also apply to firms that release more frequent, precise or accurate MEFs. Taken as a whole, our findings indicate that the quality of information not only influences firms' idiosyncratic risk, but non-diversifiable systematic risk.

We use Tobin's Q in measuring firm value. Our results demonstrate that releasing MEFs is associated with an enhancement in firm value, while more frequent, precise and accurate earnings forecasts further enhance value premiums. An interesting implication which can be gleaned from our results is that voluntary disclosure of MEFS impacts firm valuation through two channels: i.e., changes in firm risk and changes in expected future cash flows. This finding substantiates the view in Lambert et al. (2007) that disclosure may change firms’ future cash flows, not only through the perceptions of cash flows by investors,

\footnotetext{
${ }^{7}$ We employ a 1-to-N (rather than 1-to-1) matching so that all non-forecasters that meet the maximum range of propensity score of $0.1 \%$ are included into the PSM sample.
} 
but through real decisions which help better allocate capital. In general, our evidence supports that releasing high-quality MEFs is associated with significant capital market benefits.

Similar to other studies, our research is subject to caveats. First, although we try our best to control for endogeneity and self-selection issues, our results should be interpreted with cautions. Put differently, our results are based on associations and, while we view them as robust and intriguing, one cannot draw strong conclusions about causality. Second, our work mainly focuses on the perspective of shareholders, and future research may explore the economic consequences of voluntary disclosure of MEFs on other stakeholders, e.g., debtholders. 


\section{References}

Ajinkya, B., and M. Gift, 1984. Corporate managers' earnings forecasts and symmetrical adjustments of market expectations. Journal of Accounting Research 22: 425-444.

Ajinkya, B., S. Bhojraj, and P. Sengupta. 2005. The association between outside directors, institutional investors and properties of management earnings forecasts. Journal of Accounting Research 43: 343-376.

Anilowski, C., M. Feng, and D. J. Skinner. 2007. Does earnings guidance affect market returns? The nature of information content of aggregate earnings guidance. Journal of Accounting and Economics 44: 36-63.

Ashbaugh-Skaife H., D. W. Collins, W. R. Kinney, and R. Lafond. 2009. The effect of SOX internal control deficiencies on firm risk and cost of equity. Journal of Accounting Research 47: 1-43.

Baginski, S., E. Conrad, and J. Hassell. 1993. The effects of management forecast precision on equity pricing and on the assessment of earnings uncertainty. The Accounting Review 68: 913-927.

Barry, C., and S. Brown. 1985. Differential information and security market equilibrium. Journal of Financial and Quantitative Analysis 20: 407-422.

Barry, C., and S. Brown. 1986. Limited information as a source of risk. The Journal of Portfolio Management 12: 6672.

Bartram, S. M., G. W. Brown, and J. Conrad. 2011. The effects of derivatives on firm risk and value. Journal of Financial and Quantitative Analysis 46: 967-999.

Botosan, C. 1997. Disclosure level and the cost of equity capital, The Accounting Review 72: 323-350.

Botosan, C.2006. Disclosure and the cost of capital: what do we know? Accounting and Business Research, International Accounting Policy Forum: 31-40.

Botosan C. and M. S. Harris. 2000. Motivations for a change in disclosure frequency and its consequences: an examination of voluntary quarterly segment disclosures. Journal of Accounting Research 38: 329-353.

Brown, L. and M. Caylor. 2006. Corporate governance and firm performance. Journal of Accounting and Public Policy 25: 409-434.

Campbell, J.Y., M. Lettau, B.G. Malkiel, and Y. Xu. 2001. Have individual stocks become more volatile? An empirical exploration of idiosyncratic risk, Journal of Finance 56: 1-43.

Coller, M., and T. L. Yohn. 1997. Management forecasts and information asymmetry: An examination of bid-ask spreads. Journal of Accounting Research 35: 181-191.

Daske H., L. Hail, C. Leuz, and R. Verdi, 2008. Mandatory IFRS reporting around the world: early evidence on the economic consequences. Journal of Accounting Research 40: 1085-1142.

Diamond, D. W., and R. E. Verrecchia. 1991. Disclosure, liquidity and the cost of capital. The Journal of Finance 46: 1325-1359.

Doidge, C., G. A. Karolyi, and R. Stulz. 2004. Why are foreign firms listed in the U.S. worth more? Journal of Financial Economics 71: 205-238. 
Durnev, A., E. H. Kim. 2005. To steal or not to steal: firm attributes, legal environment, and valuation. The Journal of Finance 60: 1461-1493.

Easley, D. and M. O’Hara. 2004. Information and the cost of capital. The Journal of Finance 59: 1553-1583.

Francis, J., and K. Schipper. 1999. Have financial statements lost their relevance? Journal of Accounting Research 37: 319-352.

Gordon, L. A., M. P. Loeb and C-Y Tseng. 2009. Enterprise risk management and firm performance: a contingency perspective. Journal of Accounting and Public Policy 28: 301-327.

Goyal, A., and P. Santa-Clara. 2003. Idiosyncratic risk matters! The Journal of Finance 58: 975-1007.

Graham, J., C. Harvey and S. Rajgopal, 2005. The economic implications of corporate financial reporting. Journal of Accounting and Economics 40: 3-73.

Greene, W. 1997. Econometric Analysis, Third Edition. New York: Prentice-Hall.

Guay, W. R. 1999. The impact of derivatives on firm risk: an empirical examination of new derivatives users. Journal of Accounting and Economics 26: 319-351.

Healy, P. and K. Palepu. 2001. Information asymmetry, corporate disclosure, and the capital markets: A review of the empirical disclosure literature. Journal of Accounting and Economics 31: 405-440.

Heckman, J. 1979. Sample Selection Bias as a Specification Error, Econometrica 47: 153-161.

Hirst, E., L. Koonce, and S. Venkataraman, 2008. Management earnings forecasts: A review and framework. Accounting Horizons 22: 315-338.

Hughes, J. S., and S. Pae. 2004. Voluntary disclosure of precision information. Journal of Accounting and Economics: 37: 261-289.

Hutton, A. P., and P. C. Stocken. 2009. Prior forecast accuracy and investor reaction to management earnings forecasts. Working paper, Dartmouth College (Available at SSRN: http://ssrn.com/abstract_id=817108).

Kim, J-B, and H. Shi. 2012. IFRS reporting, firm-specific information flows, and institutional environments: international evidence. Review of Accounting Studies: forthcoming.

Kim, J., and Y. Shi. 2011. Voluntary disclosure and the cost of equity capital: evidence from MEFs. Journal of Accounting and Public Policy 30: 348-366.

Kim, O., and R. Verrecchia. 1991a. Trading volume and price reactions to public announcements. Journal of Accounting Research 29: 302-321.

Kim, O., and R. Verrecchia. 1991b. Market reaction to anticipated announcements. Journal of Financial Economics 30: 273-310.

Kim, O., and R. Verrecchia. 1994. Market liquidity and volume around earnings announcements. Journal of Accounting and Economics 17: 41-68.

King, R., G. Pownall and G. Waymire. 1990. Expectations adjustment via timely earnings forecast disclosure: Review, synthesis, and suggestions for future research. Journal of Accounting Literature 9: 113-144. 
Klein, R., and V. Bawa. 1976. The effect of estimation risk on optimal portfolio choice. Journal of Financial Economics 3: 215-231.

Kohlbeck, M., and B. W. Mayhew. 2011. Valuation of firms that disclose related party transactions. Journal of Accounting and Public Policy 29: 115-37.

Lambert, R., C. Leuz and R. Verrecchia. 2007, Accounting information, disclosure and the cost of capital. Journal of Accounting Research 45: 385-420.

Lang, L., and R. Stulz. 1994. Tobin's Q, corporate diversification, and firm performance. Journal of Political Economy 6: $1248-1280$.

Lang. M, K. Lins, and D. Miller. 2003. ADRs, analysts, and accuracy: Does cross listing in the United States improve a firm's information environment and increase market value? Journal of Accounting Research 41: 317-345.

Larcker, D. F., and T. O. Rusticus. 2010. On the use of instrumental variables in accounting research. Journal of Accounting and Economics 49: 186-205.

Leuz, C. and R. Verrecchia. 2000. The economic consequences of increased disclosure. Journal of Accounting Research 38: 91-124.

Al-Akra, M., and M. J. Ali. 2012. The value relevance of corporate voluntary disclosure in the Middle-East- the case of Jordan. Journal of Accounting and Public Policy: doi: 10.1016/j.jaccpubpol.2011.10.007.

Merton, R. 1987. A simple model of capital market equilibrium with incomplete information. Journal of Finance 42: 483-510.

Ng, J., I. Tuna and R. Verdi. 2008. Management forecast credibility and underreaction to news. Working paper, MIT Sloan School of Management (Available at SSRN: http://ssrn.com/ abstract=930697).

O’Hara, M. 2003. Presidential address: liquidity and price discovery. The Journal of Finance 58: 1335-1354.

Pownall, G., C. Wasley, and G. Waymire. 1993. The stock price effects of alternative types of management earnings forecasts. The Accounting Review 68: 896-912.

Rajgopal, S., and M. Venkatachalam. 2010. Financial reporting quality and idiosyncratic volatility. Journal of Accounting and Economics, forthcoming.

Rogers, J. L., D. J. Skinner and A. V. Buskirk. 2009. Earnings guidance and market uncertainty. Journal of Accounting and Economics 48: 90-109.

Rogers, J. L., and P. C. Stocken. 2005. Credibility of management forecasts. The Accounting Review 80: 1233-1260.

Sharp, William F. 1964. Capital asset prices: a theory of market equilibrium under conditions of risk. Journal of Finance 19: 425-442.

Sorescu, A. B., and J. Spanjol. 2008. Innovation's effect on firm value and risk: insights from consumer packaged goods. Journal of Marketing 72: 114-132.

Verrecchia, R. 2001. Essays on disclosure. Journal of Accounting and Economics 32: 91-180. 
Waymire, G. 1985. Earnings volatility and voluntary management forecast disclosure. Journal of Accounting Research 23: 268-295.

Welker, M. 1995. Disclosure policy, information asymmetry, and liquidity m equity markets. Contemporary Accounting Research 11: 801-827.

Williams, P.A. 1996. The relation between a prior earnings forecast by management and analyst response to a current management forecast. The Accounting Review 71: 103-115. 
Table 1

MEF Sample Breakdown

The sample contains 23,435 firm-year observations from 1998 to 2007 for 4,724 firms. The total sample of 23,435 includes 7,603 (32.4\%) firm-year observations representing 803 firms that provided annual MEFs, and 15,832 (67.6\%) observations representing 3,921 firms that did not provide annual MEFs. This table indicates the breakdown of the MEF portion.

\begin{tabular}{|l|l|l|}
\hline MEF Sample & $\begin{array}{l}\text { Observations(Firms) } \\
7,603(803)\end{array}$ & $\begin{array}{l}\text { \% of Total } \\
100 \%\end{array}$ \\
\hline Qverall & 628 & $8.3 \%$ \\
\hline Openalitative forecasts & 393 & $5.2 \%$ \\
\hline Range forecasts & 5,085 & $66.9 \%$ \\
\hline Point forecasts & 1,497 & $19.6 \%$ \\
\hline Firms with more than five forecasts & 321 & $40.1 \%$ \\
\hline
\end{tabular}


Table 2

Summary Statistics

Dependent and independent variables used in the analysis for our sample which contains 23,435 firm-year observations from 1998 to 2006 for 4,724 firms. Idiosyncratic Risk is estimated as the standard deviation of the residuals (slope coefficient) from the CAPM regression in equation (1) using monthly data; Stock Return Volatility is the annualized standard deviation of each firm's return series using monthly data; Beta is estimated as the slope coefficient from the CAPM regression in equation (1) using monthly data; Spread is calculated as the end-of-month closing bid and ask prices using prices from CRSP; Tobin's Q is computed as the market value of equity plus the book value of the total liabilities in the numerator and book value of assets in the denominator; Size represents the log of the market value of common equity, in \$millions, as of the firm's fiscal year-end; Leverage is the ratio of total liabilities to total assets measured at the fiscal year-end; Intangible is the ratio of total value of intangible assets to total assets measured at the fiscal year-end; Growth is the percentage increase in sales over the past three years; Loss is an indicator variable taking on the value of 1 if a firm reported a loss during the previous 12 months, and 0 otherwise; Dividend is the dividend yield calculated as dividend per share divided by earnings per share; ROA is the ratio of net profit to total assets; Analysts is the number of analysts following a firm in a given year.

\begin{tabular}{l|c|c|c|c|c} 
& Mean & Median & $\begin{array}{c}\text { Standard } \\
\text { Deviation }\end{array}$ & $\begin{array}{c}\mathbf{2 5}^{\text {th }} \\
\text { Percentile }\end{array}$ & $\begin{array}{c}\mathbf{7 5}^{\text {th }} \\
\text { Percentile }\end{array}$ \\
\hline Idiosyncratic Risk & 0.836 & 0.691 & 0.549 & 0.464 & 1.056 \\
Stock Return Volatility & 0.901 & 0.752 & 0.569 & 0.515 & 1.133 \\
Beta & 1.234 & 1.051 & 1.056 & 0.564 & 1.681 \\
Spread & 0.237 & 0.063 & 3.769 & 0.020 & 0.230 \\
Tobin's Q & 2.021 & 1.409 & 1.716 & 1.085 & 2.197 \\
\hline Size (raw value) & 3,940 & 526 & 17,406 & 153 & 1,807 \\
Size (log value) & 6.346 & 6.265 & 1.854 & 5.036 & 7.499 \\
Leverage & 0.552 & 0.548 & 0.282 & 0.341 & 0.748 \\
Intangible & 0.128 & 0.048 & 0.172 & 0.002 & 0.198 \\
Growth & 0.416 & 0.308 & 0.879 & 0.072 & 0.632 \\
Loss & 0.256 & 0.000 & 0.437 & 0.000 & 1.000 \\
Dividend & 0.015 & 0 & 0.094 & 0.000 & 0.017 \\
ROA & -0.024 & 0.026 & 0.425 & -0.002 & 0.070 \\
Analysts & 5.007 & 3.000 & 5.252 & 1.000 & 7.000 \\
\hline
\end{tabular}




\section{Table 3a}

\section{Relationship Between Risk Measures and MEFs}

This table presents the regression results of the effects of the occurrence of MEFs (MEF) on firm risks. The dependent variables are Idiosyncratic Risk, Stock Return Volatility, Beta, and Spread as described in Table 2. The independent variables include MEF, Size, Leverage, Intangible, Growth, Loss, Dividend as described in Table 2, and Industry and Year Dummies. We use a series of ten industry classifications based on the standard break-down according to two-digit SIC codes. Specifically, we define the industries as agriculture/forestry/fishing, mining, construction, manufacturing, transportation, wholesale trade, retail trade, finance/insurance/real estate, services and other. The coefficients on Industry and Year dummies are not reported in this table. For each regression the first row is the coefficient estimates, the second row is the standard errors, and the third row is the t-statistics.

\begin{tabular}{|c|c|c|c|c|c|c|c|c|c|}
\hline & Intercept & MEF & Size & Leverage & Intangible & Growth & Loss & Dividend & $\mathrm{R}^{2}$ \\
\hline Idiosyncratic Risk & 1.1269 & -0.0425 & -0.0764 & -0.0877 & -0.0657 & 0.0588 & 0.3274 & -0.0249 & 0.39 \\
\hline Standard Error & 0.0604 & 0.0067 & 0.0018 & 0.0139 & 0.0186 & 0.0033 & 0.0076 & 0.0297 & \\
\hline T-statistic & 18.67 & -6.31 & -42.18 & -6.31 & -3.53 & 17.41 & 43.22 & -0.84 & \\
\hline Stock Return Volatility & 1.1367 & -0.0545 & -0.0694 & -0.1137 & -0.0707 & 0.0600 & 0.3634 & -0.0335 & 0.39 \\
\hline Standard Error & 0.0630 & 0.0070 & 0.0019 & 0.0145 & 0.0194 & 0.0035 & 0.0079 & 0.0311 & \\
\hline T-statistic & 18.04 & -7.75 & -36.74 & -7.84 & -3.64 & 17.01 & 45.96 & -1.08 & \\
\hline Beta & 1.5463 & -0.1706 & 0.0336 & -0.3698 & -0.1101 & 0.0538 & 0.5786 & -0.1377 & 0.16 \\
\hline Standard Error & 0.1394 & 0.0156 & 0.0042 & 0.0321 & 0.0429 & 0.0078 & 0.0175 & 0.0687 & \\
\hline T-statistic & 11.09 & -10.96 & 8.03 & -11.52 & -2.56 & 6.89 & 33.07 & -2.00 & \\
\hline Spread & 29.0444 & -0.2904 & 0.1017 & -0.1108 & -0.1383 & 0.0400 & -0.1462 & -0.1929 & 0.14 \\
\hline Standard Error & 0.5397 & 0.0602 & 0.0162 & 0.1243 & 0.1662 & 0.0302 & 0.0677 & 0.2660 & \\
\hline T-statistic & 53.82 & -4.82 & 6.28 & -0.89 & -0.83 & 1.33 & -2.16 & -0.72 & \\
\hline
\end{tabular}


Table 3b

Relationship Between Firm Value and MEFs

This table reports the regression results of the effects of the occurrence of MEFs on firm valuation. The dependent variable is Tobin's Q as described in Table 2. Other independent variables include Size, Leverage, Growth, ROA, Analyst, one risk measure (i.e., Idiosyncratic Risk, Stock Return Volatility, Beta, or Average Spread) and Industry and Year Dummies. All these variables are described in Table 2. The coefficients on Industry and Year dummies are not reported in this table. For each regression the first row is the coefficient estimates, the second row is the standard errors, and the third row is the t-statistics.

\begin{tabular}{|c|c|c|c|c|c|c|c|c|c|}
\hline $\begin{array}{l}\text { Dependent variable: Tobin’s Q; } \\
\text { "Risk” independent variable: }\end{array}$ & Intercept & MEF & Size & Leverage & Growth & ROA & Analyst & Risk & $\mathrm{R}^{2}$ \\
\hline No Risk Measure & 3.3458 & 0.1264 & -0.2088 & -0.8899 & 0.1763 & 0.1142 & 0.0670 & & 0.17 \\
\hline Standard Error & 0.2130 & 0.0232 & 0.0077 & 0.0501 & 0.0116 & 0.0613 & 0.0023 & & \\
\hline T-statistic & 15.71 & 5.46 & -27.00 & -17.75 & 15.27 & 1.86 & 28.37 & & \\
\hline Idiosyncratic Risk & 2.9438 & 0.1452 & -0.1840 & -0.8410 & 0.1584 & 0.3615 & 0.0659 & 0.3310 & 0.17 \\
\hline Standard Error & 0.2140 & 0.0231 & 0.0079 & 0.0500 & 0.0116 & 0.0636 & 0.0024 & 0.0238 & \\
\hline T-statistic & 13.76 & 6.29 & -23.28 & -16.81 & 13.69 & 5.69 & 28.00 & 13.96 & \\
\hline Stock Return Volatility & 2.9611 & 0.1480 & -0.1869 & -0.8369 & 0.1592 & 0.3663 & 0.0654 & 0.3098 & 0.17 \\
\hline Standard Error & 0.2140 & 0.0231 & 0.0078 & 0.0501 & 0.0116 & 0.0638 & 0.0024 & 0.0228 & \\
\hline T-statistic & 13.84 & 6.40 & -23.74 & -16.71 & 13.77 & 5.74 & 27.75 & 13.61 & \\
\hline Beta & 3.2758 & 0.1338 & -0.2091 & -0.8746 & 0.1744 & 0.1585 & 0.0662 & 0.0396 & 0.17 \\
\hline Standard Error & 0.2137 & 0.0232 & 0.0077 & 0.0503 & 0.0116 & 0.0624 & 0.0024 & 0.0104 & \\
\hline T-statistic & 15.33 & 5.76 & -27.04 & -17.39 & 15.09 & 2.54 & 27.94 & 3.80 & \\
\hline Average Spread & 3.2654 & 0.1271 & -0.2093 & -0.8892 & 0.1762 & 0.1144 & 0.0671 & 0.0029 & 0.17 \\
\hline Standard Error & 0.2265 & 0.0232 & 0.0077 & 0.0501 & 0.0116 & 0.0613 & 0.0024 & 0.0028 & \\
\hline T-statistic & 14.42 & 5.49 & -27.01 & -17.74 & 15.26 & 1.87 & 28.39 & 1.04 & \\
\hline
\end{tabular}




\section{Table 4a}

\section{Relationship Between Risk Measures and MEFs Frequency}

This table presents the regression results of the effects of the frequency of MEFs (Frequency) on firm risks. The dependent variables are Idiosyncratic Risk, Stock Return Volatility, Beta, and Spread as described in Table 2. The independent variables include Frequency, Size, Leverage, Intangible, Growth, Loss, Dividend as described in Table 2, and Industry and Year Dummies. We use a series of ten industry classifications based on the standard break-down according to two-digit SIC codes. Specifically, we define the industries as agriculture/forestry/fishing, mining, construction, manufacturing, transportation, wholesale trade, retail trade, finance/insurance/real estate, services and other. The coefficients on Industry and Year dummies are not reported in this table. For each regression the first row is the coefficient estimates, the second row is the standard errors, and the third row is the t-statistics.

\begin{tabular}{|c|c|c|c|c|c|c|c|c|c|}
\hline & Intercept & Frequency & Size & Leverage & Intangible & Growth & Loss & Dividend & $\mathrm{R}^{2}$ \\
\hline Idiosyncratic Risk & 1.1333 & -0.0310 & -0.0745 & -0.0869 & -0.0577 & 0.0579 & 0.3257 & -0.0238 & 0.40 \\
\hline Standard Error & 0.0603 & 0.0034 & 0.0018 & 0.0139 & 0.0186 & 0.0034 & 0.0076 & 0.0297 & \\
\hline T-statistic & 18.79 & -9.22 & -40.74 & -6.26 & -3.10 & 17.14 & 43.07 & -0.80 & \\
\hline Stock Return Volatility & 1.1449 & -0.0390 & -0.0671 & -0.1126 & -0.0610 & 0.0588 & 0.3613 & -0.0320 & 0.39 \\
\hline Standard Error & 0.0629 & 0.0035 & 0.0019 & 0.0145 & 0.0194 & 0.0035 & 0.0079 & 0.0310 & \\
\hline T-statistic & 18.20 & -11.09 & -35.19 & -7.77 & -3.14 & 16.70 & 45.81 & -1.03 & \\
\hline Beta & 1.5726 & -0.1267 & 0.0415 & -0.3664 & -0.0768 & 0.0500 & 0.5712 & -0.1330 & 0.16 \\
\hline Standard Error & 0.1390 & 0.0078 & 0.0042 & 0.0320 & 0.0429 & 0.0078 & 0.0174 & 0.0685 & \\
\hline T-statistic & 11.32 & -16.33 & 9.86 & -11.45 & -1.79 & 6.42 & 32.79 & -1.94 & \\
\hline Spread & 29.0811 & -0.1693 & 0.1085 & -0.1058 & -0.1119 & 0.0346 & -0.1488 & -0.1847 & 0.14 \\
\hline Standard Error & 0.5396 & 0.0301 & 0.0164 & 0.1243 & 0.1664 & 0.0302 & 0.0677 & 0.2660 & \\
\hline T-statistic & 53.90 & -5.62 & 6.63 & -0.85 & -0.67 & 1.14 & -2.20 & -0.69 & \\
\hline
\end{tabular}


Table 4b

Relationship Between Firm Value and MEFs Frequency

This table reports the regression results of the effects of the frequency of MEFs on firm valuation. The dependent variable is Tobin's Q as described in Table 2. Other independent variables include Size, Leverage, Growth, ROA, Analyst, one risk measure (i.e., Idiosyncratic Risk, Stock

Return Volatility, Beta, or Average Spread) and Industry and Year Dummies. All these variables are described in Table 2. The coefficients on Industry and Year dummies are not reported in this table. For each regression the first row is the coefficient estimates, the second row is the standard errors, and the third row is the t-statistics.

\begin{tabular}{|c|c|c|c|c|c|c|c|c|c|}
\hline $\begin{array}{l}\text { Panel B } \\
\text { Dependent variable: Tobin’s Q; } \\
\text { "Risk” independent variable: }\end{array}$ & Intercept & Frequency & Size & Leverage & Growth & ROA & Analyst & Risk & $\mathrm{R}^{2}$ \\
\hline No Risk Measure & 3.3299 & 0.0651 & -0.2101 & -0.8920 & 0.1784 & 0.1190 & 0.0668 & & \multirow{3}{*}{0.17} \\
\hline Standard Error & 0.2130 & 0.0118 & 0.0078 & 0.0501 & 0.0115 & 0.0613 & 0.0024 & & \\
\hline T-statistic & 15.64 & 5.54 & -27.01 & -17.79 & 15.46 & 1.94 & 28.25 & & \\
\hline Idiosyncratic Risk & 2.9196 & 0.0786 & -0.1857 & -0.8429 & 0.1606 & 0.3693 & 0.0656 & 0.3353 & \multirow[t]{3}{*}{0.17} \\
\hline Standard Error & 0.2140 & 0.0117 & 0.0079 & 0.0500 & 0.0116 & 0.0635 & 0.0024 & 0.0237 & \\
\hline T-statistic & 13.64 & 6.70 & -23.41 & -16.84 & 13.89 & 5.81 & 27.84 & 14.12 & \\
\hline Stock Return Volatility & 2.9354 & 0.0806 & -0.1887 & -0.8386 & 0.1615 & 0.3749 & 0.0650 & 0.3148 & \multirow[t]{3}{*}{0.17} \\
\hline Standard Error & 0.2140 & 0.0118 & 0.0079 & 0.0501 & 0.0116 & 0.0638 & 0.0024 & 0.0228 & \\
\hline T-statistic & 13.72 & 6.86 & -23.88 & -16.75 & 13.97 & 5.88 & 27.58 & 13.80 & \\
\hline Beta & 3.2534 & 0.0712 & -0.2108 & -0.8758 & 0.1765 & 0.1663 & 0.0659 & 0.0425 & \multirow[t]{3}{*}{0.17} \\
\hline Standard Error & 0.2137 & 0.0118 & 0.0078 & 0.0503 & 0.0116 & 0.0624 & 0.0024 & 0.0105 & \\
\hline T-statistic & 15.22 & 6.01 & -27.11 & -17.42 & 15.28 & 2.67 & 27.77 & 4.06 & \\
\hline Average Spread & 3.2472 & 0.0655 & -0.2106 & -0.8913 & 0.1783 & 0.1192 & 0.0668 & 0.0030 & \multirow[t]{3}{*}{0.17} \\
\hline Standard Error & 0.2265 & 0.0118 & 0.0078 & 0.0501 & 0.0115 & 0.0613 & 0.0024 & 0.0028 & \\
\hline T-statistic & 14.34 & 5.57 & -27.03 & -17.78 & 15.45 & 1.95 & 28.27 & 1.07 & \\
\hline
\end{tabular}




\section{Table 5a}

Relationship Between Risk Measures and MEFs Precision

This table presents the regression results of the effects of the precision of MEFs (Precision) on firm risks. The dependent variables are Idiosyncratic Risk, Stock Return Volatility, Beta, and Spread as described in Table 2. The independent variables include Precision, Size, Leverage, Intangible, Growth, Loss, Dividend as described in Table 2, and Industry and Year Dummies. We use a series of ten industry classifications based on the standard break-down according to two-digit SIC codes. Specifically, we define the industries as agriculture/forestry/fishing, mining, construction, manufacturing, transportation, wholesale trade, retail trade, finance/insurance/real estate, services and other. The coefficients on Industry and Year dummies are not reported in this table. For each regression the first row is the coefficient estimates, the second row is the standard errors, and the third row is the t-statistics.

\begin{tabular}{|c|c|c|c|c|c|c|c|c|c|}
\hline & Intercept & Precision & Size & Leverage & Intangible & Growth & Loss & Dividend & $\mathrm{R}^{2}$ \\
\hline Idiosyncratic Risk & 1.1264 & -0.0317 & -0.0764 & -0.0878 & -0.0654 & 0.0588 & 0.3269 & -0.0252 & 0.39 \\
\hline Standard Error & 0.0604 & 0.0049 & 0.0018 & 0.0139 & 0.0186 & 0.0034 & 0.0076 & 0.0298 & \\
\hline T-statistic & 18.66 & -6.53 & -42.22 & -6.32 & -3.52 & 17.41 & 43.13 & -0.85 & \\
\hline Stock Return Volatility & 1.1361 & -0.0407 & -0.0694 & -0.1138 & -0.0703 & 0.0600 & 0.3627 & -0.0337 & 0.39 \\
\hline Standard Error & 0.0629 & 0.0051 & 0.0019 & 0.0145 & 0.0194 & 0.0035 & 0.0079 & 0.0311 & \\
\hline T-statistic & 18.04 & -8.03 & -36.76 & -7.85 & -3.62 & 17.01 & 45.85 & -1.09 & \\
\hline Beta & 1.5444 & -0.1282 & 0.0338 & -0.3703 & -0.1086 & 0.0538 & 0.5764 & -0.1385 & 0.16 \\
\hline Standard Error & 0.1394 & 0.0112 & 0.0042 & 0.0321 & 0.0429 & 0.0078 & 0.0175 & 0.0687 & \\
\hline T-statistic & 11.08 & -11.43 & 8.09 & -11.53 & -2.53 & 6.89 & 32.93 & -2.02 & \\
\hline Spread & 29.0421 & -0.1998 & 0.1005 & -0.1114 & -0.1432 & 0.0399 & -0.1468 & -0.1934 & 0.14 \\
\hline Standard Error & 0.5397 & 0.0435 & 0.0162 & 0.1243 & 0.1662 & 0.0302 & 0.0678 & 0.2660 & \\
\hline T-statistic & 53.81 & -4.60 & 6.21 & -0.90 & -0.86 & 1.32 & -2.17 & -0.73 & \\
\hline
\end{tabular}


Table $5 b$

Relationship Between Firm Value and MEFs Precision

This table reports the regression results of the effects of the precision of MEFs on firm valuation. The dependent variable is Tobin's Q as described in Table 2. Other independent variables include Size, Leverage, Growth, ROA, Analyst, one risk measure (i.e., Idiosyncratic Risk, Stock Return Volatility, Beta, or Average Spread) and Industry and Year Dummies. All these variables are described in Table 2. The coefficients on Industry and Year dummies are not reported in this table. For each regression the first row is the coefficient estimates, the second row is the standard errors, and the third row is the t-statistics.

\begin{tabular}{|c|c|c|c|c|c|c|c|c|c|}
\hline $\begin{array}{l}\text { Dependent variable: Tobin's Q; } \\
\text { "Risk” independent variable: }\end{array}$ & Intercept & Precision & Size & Leverage & Growth & ROA & Analyst & Risk & $\mathrm{R}^{2}$ \\
\hline No Risk Measure & 3.3462 & 0.0840 & -0.2080 & -0.8897 & 0.1765 & 0.1142 & 0.0670 & & \multirow[t]{3}{*}{0.17} \\
\hline Standard Error & 0.2130 & 0.0167 & 0.0077 & 0.0501 & 0.0116 & 0.0614 & 0.0024 & & \\
\hline T-statistic & 15.71 & 5.02 & -26.91 & -17.75 & 15.29 & 1.86 & 28.37 & & \\
\hline Idiosyncratic Risk & 2.9447 & 0.9780 & -0.1832 & -0.8408 & 0.1585 & 0.3608 & 0.0659 & 0.3307 & \multirow[t]{3}{*}{0.17} \\
\hline Standard Error & 0.2140 & 0.0167 & 0.0079 & 0.0501 & 0.0116 & 0.0636 & 0.0024 & 0.0237 & \\
\hline T-statistic & 13.76 & 5.87 & -23.20 & -16.80 & 13.70 & 5.67 & 27.99 & 13.95 & \\
\hline Stock Return Volatility & 2.9621 & 0.1001 & -0.1861 & -0.8366 & 0.1594 & 0.3655 & 0.0654 & 0.3095 & \multirow[t]{3}{*}{0.17} \\
\hline Standard Error & 0.2140 & 0.0167 & 0.0079 & 0.0501 & 0.0116 & 0.0638 & 0.0024 & 0.0228 & \\
\hline T-statistic & 13.84 & 6.00 & -23.66 & -16.70 & 13.78 & 5.73 & 27.75 & 13.59 & \\
\hline Beta & 3.2766 & 0.0896 & -0.2083 & -0.8744 & 0.1746 & 0.1582 & 0.0662 & 0.0395 & \multirow[t]{3}{*}{0.17} \\
\hline Standard Error & 0.2137 & 0.0168 & 0.0077 & 0.0503 & 0.0116 & 0.0624 & 0.0024 & 0.0104 & \\
\hline T-statistic & 15.33 & 5.34 & -26.96 & -17.39 & 15.11 & 2.53 & 27.94 & 3.78 & \\
\hline Average Spread & 3.2674 & 0.0845 & -0.2084 & -0.8890 & 0.1764 & 0.1144 & 0.0671 & 0.0029 & \multirow[t]{3}{*}{0.17} \\
\hline Standard Error & 0.2265 & 0.0167 & 0.0077 & 0.0502 & 0.0116 & 0.0614 & 0.0024 & 0.0028 & \\
\hline T-statistic & 14.43 & 5.05 & -26.93 & -17.73 & 15.27 & 1.86 & 28.39 & 1.02 & \\
\hline
\end{tabular}




\section{Table 6a}

\section{Relationship Between Risk Measures and MEFs Error}

This table presents the regression results of the effects of the error of MEFs (Error) on firm risks. The dependent variables are Idiosyncratic Risk, Stock Return Volatility, Beta, and Spread as described in Table 2. The independent variables include Error, Size, Leverage, Intangible, Growth, Loss, Dividend as described in Table 2, and Industry and Year Dummies. We use a series of ten industry classifications based on the standard break-down according to two-digit SIC codes. Specifically, we define the industries as agriculture/forestry/fishing, mining, construction, manufacturing, transportation, wholesale trade, retail trade, finance/insurance/real estate, services and other. The coefficients on Industry and Year dummies are not reported in this table. For each regression the first row is the coefficient estimates, the second row is the standard errors, and the third row is the t-statistics.

\begin{tabular}{l|ccccccccc} 
& Intercept & Error & Size & Leverage & Intangible & Growth & Loss & Dividend & $\mathrm{R}^{2}$ \\
\hline Idiosyncratic Risk & 1.1284 & 0.0190 & -0.0789 & -0.0885 & -0.0776 & 0.0583 & 0.3320 & -0.0236 & 0.39 \\
Standard Error & 0.0604 & 0.0076 & 0.0018 & 0.0139 & 0.0185 & 0.0034 & 0.0075 & 0.0298 \\
T-statistic & 18.68 & 2.52 & -44.72 & -6.36 & -4.19 & 17.24 & 44.02 & -0.79 \\
\hline Stock Return Volatility & 1.1386 & 0.0210 & -0.0727 & -0.1145 & -0.0860 & 0.0594 & 0.3693 & -0.0316 & 0.39 \\
Standard Error & 0.0631 & 0.0079 & 0.0018 & 0.0145 & 0.0193 & 0.0035 & 0.0079 & 0.0311 \\
T-statistic & 18.05 & 2.67 & -39.45 & -7.88 & -4.45 & 16.82 & 46.89 & -1.02 & -0.1322 \\
\hline Beta & 1.5518 & 0.0453 & 0.0233 & -0.3711 & -0.1585 & 0.0522 & 0.5976 & 0.15 \\
Standard Error & 0.1398 & 0.0175 & 0.0041 & 0.0322 & 0.0428 & 0.0078 & 0.0175 & 0.0689 \\
T-statistic & 11.10 & 2.59 & 5.70 & -11.52 & -3.70 & 6.67 & 34.23 & -1.92 \\
\hline Spread & 29.0516 & -0.0085 & 0.0084 & -0.1084 & -0.2224 & 0.0385 & -0.1122 & -0.1841 & 0.13 \\
Standard Error & 0.5400 & 0.0675 & 0.0158 & 0.1244 & 0.1654 & 0.0302 & 0.0674 & 0.2662 \\
T-statistic & 53.80 & -0.13 & 5.33 & -0.87 & -1.34 & 1.27 & -1.66 & -0.69 \\
\hline
\end{tabular}


Table 6b

Relationship Between Firm Value and MEFs Error

This table reports the regression results of the effects of the error of MEFs on firm valuation. The dependent variable is Tobin's Q as described in Table 2. Other independent variables include Size, Leverage, Growth, ROA, Analyst, one risk measure (i.e., Idiosyncratic Risk, Stock Return Volatility, Beta, or Average Spread) and Industry and Year Dummies. All these variables are described in Table 2. The coefficients on Industry and Year dummies are not reported in this table. For each regression the first row is the coefficient estimates, the second row is the standard errors, and the third row is the t-statistics.

\begin{tabular}{|c|c|c|c|c|c|c|c|c|c|}
\hline $\begin{array}{l}\text { Dependent variable: Tobin’s Q; } \\
\text { "Risk” independent variable: }\end{array}$ & Intercept & Error & Size & Leverage & Growth & ROA & Analyst & Risk & $\mathrm{R}^{2}$ \\
\hline No Risk Measure & 3.3388 & -0.0666 & -0.2004 & -0.8888 & 0.1788 & 0.1214 & 0.0672 & & 0.17 \\
\hline Standard Error & 0.2131 & 0.0258 & 0.0076 & 0.0502 & 0.0116 & 0.0615 & 0.0024 & & \\
\hline T-statistic & 15.67 & -2.58 & -26.35 & -17.72 & 15.47 & 1.98 & 28.45 & & \\
\hline Idiosyncratic Risk & 2.9470 & -0.0668 & -0.1750 & -0.8410 & 0.1615 & 0.3650 & 0.0662 & 0.3223 & 0.17 \\
\hline Standard Error & 0.2142 & 0.0257 & 0.0078 & 0.0501 & 0.0116 & 0.0638 & 0.0024 & 0.0237 & \\
\hline T-statistic & 13.76 & -2.60 & -22.45 & -16.79 & 13.94 & 5.72 & 28.10 & 13.61 & \\
\hline Stock Return Volatility & 2.9660 & -0.0670 & -0.1778 & -0.8373 & 0.1624 & 0.3686 & 0.0657 & 0.2998 & 0.17 \\
\hline Standard Error & 0.2141 & 0.0257 & 0.0078 & 0.0501 & 0.0116 & 0.0640 & 0.0024 & 0.0227 & \\
\hline T-statistic & 13.85 & -2.61 & -22.90 & -16.70 & 14.03 & 5.76 & 27.87 & 13.19 & \\
\hline Beta & 3.2771 & -0.0676 & -0.2002 & -0.8752 & 0.1771 & 0.1612 & 0.0665 & 0.0348 & 0.17 \\
\hline Standard Error & 0.2138 & 0.0258 & 0.0076 & 0.0503 & 0.0116 & 0.0626 & 0.0024 & 0.0104 & \\
\hline T-statistic & 15.33 & -2.62 & -26.34 & -17.40 & 15.32 & 2.58 & 28.07 & 3.35 & \\
\hline Average Spread & 3.2720 & -0.0666 & -0.2007 & -0.8881 & 0.1787 & 0.1217 & 0.0673 & 0.0024 & 0.17 \\
\hline Standard Error & 0.2266 & 0.0258 & 0.0076 & 0.0502 & 0.0116 & 0.0615 & 0.0024 & 0.0028 & \\
\hline T-statistic & 14.44 & -2.58 & -26.36 & -17.70 & 15.46 & 1.98 & 28.46 & 0.87 & \\
\hline
\end{tabular}




\section{Table 7a}

\section{Relationship Between Risk Measures and MEFs-Propensity Score Matching (PSM) Method}

Basing on the PSM sample of 14,806 firm-year observations of both forecasters and non-forecasters, this table presents the regression results of the effects of the occurrence of MEFs (MEF) on firm risks. The dependent variables are Idiosyncratic Risk, Stock Return Volatility, Beta, and Spread as described in Table 2. The independent variables include MEF, Size, Leverage, Intangible, Growth, Loss, Dividend as described in Table 2, and Industry and Year Dummies. We use a series of ten industry classifications based on the standard break-down according to two-digit SIC codes. Specifically, we define the industries as agriculture/forestry/fishing, mining, construction, manufacturing, transportation, wholesale trade, retail trade, finance/insurance/real estate, services and other. The coefficients on Industry and Year dummies are not reported in this table. For each regression the first row is the coefficient estimates, the second row is the standard errors, and the third row is the t-statistics.

\begin{tabular}{|c|c|c|c|c|c|c|c|c|c|}
\hline & Intercept & MEF & Size & Leverage & Intangible & Growth & Loss & Dividend & $\mathrm{R}^{2}$ \\
\hline Idiosyncratic Risk & 0.9492 & -0.0359 & -0.0726 & -0.0562 & -0.1254 & 0.0930 & 0.3066 & -1.0047 & 0.38 \\
\hline Standard Error & 0.0609 & 0.0064 & 0.0020 & 0.0162 & 0.0194 & 0.0046 & 0.0090 & 0.1013 & \\
\hline T-statistic & 15.57 & -5.57 & -36.07 & -3.46 & -6.44 & 20.05 & 34.06 & -9.91 & \\
\hline Stock Return Volatility & 0.9617 & -0.0467 & -0.0663 & -0.0791 & -0.1384 & 0.0965 & 0.3431 & -1.1800 & 0.37 \\
\hline Standard Error & 0.0640 & 0.0067 & 0.0021 & 0.0170 & 0.0204 & 0.0049 & 0.0094 & 0.1065 & \\
\hline T-statistic & 15.01 & -6.90 & -31.30 & -4.65 & -6.76 & 19.79 & 36.27 & -11.08 & \\
\hline Beta & 1.3935 & -0.1622 & 0.0171 & -0.2591 & -0.3091 & 0.1133 & 0.5720 & -2.6755 & 0.14 \\
\hline Standard Error & 0.1493 & 0.0158 & 0.0049 & 0.0397 & 0.0477 & 0.0114 & 0.0221 & 0.2483 & \\
\hline T-statistic & 9.33 & -10.28 & 3.46 & -6.52 & -6.47 & 9.97 & 25.93 & -10.78 & \\
\hline Spread & 59.6865 & -0.3521 & 0.1568 & -0.5719 & -0.1611 & 0.1700 & -0.1102 & -2.0732 & 0.29 \\
\hline Standard Error & 0.8666 & 0.0916 & 0.0286 & 0.2305 & 0.2770 & 0.0660 & 0.1280 & 1.4409 & \\
\hline T-statistic & 68.87 & -3.85 & 5.48 & -2.48 & -0.58 & 2.58 & -0.86 & -1.44 & \\
\hline
\end{tabular}


Table $7 \mathbf{b}$

Relationship Between Firm Value and MEFs - Propensity Score Matching (PSM) Method

Basing on the PSM sample of 14,806 firm-year observations of both forecasters and non-forecasters, this table reports the regression results of the effects of the occurrence of MEFs on firm valuation. The dependent variable is Tobin's Q as described in Table 2. Other independent variables include Size, Leverage, Growth, ROA, Analyst, one risk measure (i.e., Idiosyncratic Risk, Stock Return Volatility, Beta, or Average Spread) and Industry and Year Dummies. All these variables are described in Table 2. The coefficients on Industry and Year dummies are not reported in this table. For each regression the first row is the coefficient estimates, the second row is the standard errors, and the third row is the t-statistics.

\begin{tabular}{|c|c|c|c|c|c|c|c|c|c|}
\hline $\begin{array}{l}\text { Dependent variable: Tobin’s Q; } \\
\text { "Risk” independent variable: }\end{array}$ & Intercept & MEF & Size & Leverage & Growth & ROA & Analyst & Risk & $\mathrm{R}^{2}$ \\
\hline No Risk Measure & 2.4506 & 0.0820 & -0.1168 & -0.9663 & 0.3451 & 2.2751 & 0.0516 & & \multirow[t]{3}{*}{0.22} \\
\hline Standard Error & 0.2125 & 0.0217 & 0.0083 & 0.0573 & 0.0157 & 0.0880 & 0.0021 & & \\
\hline T-statistic & 11.53 & 3.78 & -14.04 & -16.88 & 21.95 & 25.84 & 24.24 & & \\
\hline Idiosyncratic Risk & 2.0798 & 0.0959 & -0.0894 & -0.9357 & 0.3169 & 2.5498 & 0.0502 & 0.3363 & \multirow[t]{3}{*}{0.23} \\
\hline Standard Error & 0.2139 & 0.0216 & 0.0086 & 0.0570 & 0.0158 & 0.0907 & 0.0021 & 0.0287 & \\
\hline T-statistic & 9.72 & 4.43 & -10.38 & -16.40 & 20.01 & 28.11 & 23.68 & 11.73 & \\
\hline Stock Return Volatility & 2.0840 & 0.0987 & -0.0915 & -0.9302 & 0.3174 & 2.5686 & 0.0498 & 0.3220 & \multirow[t]{3}{*}{0.23} \\
\hline Standard Error & 0.2138 & 0.0217 & 0.0086 & 0.0570 & 0.0158 & 0.0911 & 0.0021 & 0.0273 & \\
\hline T-statistic & 9.75 & 4.56 & -10.70 & -16.30 & 20.06 & 28.20 & 23.45 & 11.79 & \\
\hline Beta & 2.3763 & 0.0891 & -0.1158 & -0.9550 & 0.3409 & 2.3366 & 0.0508 & 0.0436 & \multirow[t]{3}{*}{0.22} \\
\hline Standard Error & 0.2134 & 0.0218 & 0.0083 & 0.0573 & 0.0157 & 0.0896 & 0.0021 & 0.0118 & \\
\hline T-statistic & 11.14 & 4.09 & -13.91 & -16.66 & 21.63 & 26.08 & 23.77 & 3.67 & \\
\hline Average Spread & 2.4140 & 0.0822 & -0.1170 & -0.9658 & 0.3450 & 2.2752 & 0.0516 & 0.0006 & \multirow[t]{3}{*}{0.22} \\
\hline Standard Error & 0.2448 & 0.0217 & 0.0083 & 0.0573 & 0.0157 & 0.0880 & 0.0021 & 0.0021 & \\
\hline T-statistic & 9.86 & 3.78 & -14.02 & -16.86 & 21.93 & 25.84 & 24.23 & 0.30 & \\
\hline
\end{tabular}

